\title{
Enterprise Mix in Integrated Fish Farming in Ogun State, Nigeria
}

\author{
B. G. Abiona
}

Department of Agricultural Extension and Rural Development

University of Agriculture, P. M. B. 2240 Abeokuta, Ogun State, Nigeria

Tel: 234-70-3643-5769 E-mail: dolace6ng@yahoo.com

E. O Fakoya

Department of Agricultural Extension and Rural Development

University of Agriculture, P. M. B. 2240 Abeokuta, Ogun State, Nigeria

Tel: 234-80-3484-0333Ｅ-mail: fakoya@yahoo.com

S.O. Apantaku

Department of Agricultural Extension and Rural Development

University of Agriculture, P. M. B. 2240 Abeokuta, Ogun State, Nigeria

Tel: 234-80-3864-8563 E-mail: samapantaku@yahoo.com

W.O. Alegbeleye

Department of Aquaculture and Fishery

University of Agriculture, P. M. B. 2240 Abeokuta, Ogun State, Nigeria

Tel: 234-80-3382-4292 E-mail: segunalegbeleye@yahoo.com

C. I. Sodiya

Department of Agricultural Extension and Rural Development

University of Agriculture, P. M. B. 2240 Abeokuta, Ogun State, Nigeria

Tel: 234-70-3570-2655Ｅ-mail: sinaronke@yahoo.com

T. O. A. Banmeke

Department of Agricultural Extension and Rural Development

University of Agriculture, P. M. B. 2240 Abeokuta, Ogun State, Nigeria

Tel: 234-80-3484-0333 E-mail: toabanmeke@gmail.com

R. A. Oyeyinka

Department of Agricultural Administration

University of Agriculture, P. M. B. 2240 Abeokuta, Ogun State, Nigeria

Tel: 234-80-3379-8232 E-mail: akinoye2009@gmail.com

\section{A.K. Aromolaran}

Department of Agricultural Extension and Rural Development University of Agriculture, P. M. B. 2240 Abeokuta, Ogun State, Nigeria

Tel: 234-80-3487-8508 E-mail: garomolaran@yahoo.com

Received: March 16, 2011

doi:10.5539/jas.v4n1p171
Accepted: April 12, $2011 \quad$ Online Published: December 1, 2011

URL: http://dx.doi.org/10.5539/jas.v4n1p171 


\begin{abstract}
The study examined enterprise mix in integrated fish farming in Ogun Satate, Nigeria. Using survey research, a pre-tested structured interview guide was used to elicit information from 216 integrated fish farmers that was purposively selected from twenty two villages in four blocks of Ogun State Agricultural development using sampling frame Descriptive and inferential statistics were used to analyze the data. Results showed that $90.7 \%$ of IFF was male. Also, $96.8 \%$ of IFF was married. The mean ages of sampled farmers were 46 years (IFF) while the mean fish farming experience was 5 years (IFF).The mean fish production capacity of NIFF was 1,894 fish. Furthermore, $11.5 \%$ of IFF integrates fish farming with poultry, $7.2 \%$ with piggery, and $15.8 \%$ and $1.4 \%$ with crops and small ruminants respectively. The chi-square analyses showed that knowledge of fish farming had significant association with respondents $\operatorname{sex}\left(\chi^{2}=9.44, \mathrm{df}=2, \mathrm{p}<0.05\right)$, marital status $\left(\chi^{2}=23.2, \mathrm{df}=4, \mathrm{p}<\right.$ $0.05)$, occupation $\left(\chi^{2}=25.5, \mathrm{df}=8, \mathrm{p}<0.05\right)$, Bivariate correlation analyses showed significant relationship between farmers knowledge and age $(r=0.20, p<0.05)$, fish farming experience $(r=0.17, p<0.05)$, level of cosmopoliteness $(\mathrm{r}=0.16, \mathrm{p}<0.05)$, livestock population capacity $(\mathrm{r}=0.21, \mathrm{p}<0.05)$, fish production capacity $(\mathrm{r}=0.36, \mathrm{p}<0.05)$, area of land cultivated $(\mathrm{r}=0.55, \mathrm{p}<0.05)$ and production constraints $(\mathrm{r}=-0.00, \mathrm{p}<0.05)$.
\end{abstract}

Keywords: Enterprise mix, Aquaculture, Agriculture, Integration and awareness

\title{
1. Introduction
}

Agriculture-Aquaculture integration is a complementary interaction between crops livestock and fish in such a way that limited land can be used for different purposes by which waste from one unit can be used to serve as input for other unit. Agriculture- aquaculture promotes efficient utilization of farm space for multiple productions (Eyo et al; 2006). The full integration of crops, livestock and fish production into the same unit is a gradual process which intervenes in various climatic and environmental conditions. The combination of two or more enterprise further even out labour demand during the year and also the re-cycling of organic waste for fish culture serves the dual purpose of clencing the environment( by avoiding the problem of waste disposal) and providing economic benefit(Nash et al ;1980, Oladosu et al; 1990). More so, most of the farmers are aware of the importance of enterprise mix in integrated fish farming, despite the fact that most of them are resources handicapped (in terms of land, labour and capital) and these has been the major challenges faced by resources poor farmers in developing countries especially Africa. Effort should be made to increase production through integration of various production system such as animal cum fish or crop-cum-fish culture for efficient utilization of available mearger resources and maximization of production which will increase the income of the farmers and would enhance food production(Chaplin et al; 2002). Based on this, the studies identify various enterprise combinations in integrated fish farming in Ogun State, Nigeria. The study describes.

\subsection{Objective of the study}

\section{Broad objective}

The general objective of the study is to assess enterprise mix in integrated fish farming in Ogun State, Nigeria

\subsection{Specific Objectives}

1) Describe the socio-economic characteristics of integrated fish farmers and non - fish farmers in Ogun State.

2) Identify various farming enterprise combinations in integrated fish farming in the study area.

\subsection{Hypotheses of the study}

Based on the drawn up objectives, the null hypothesis was tested:

Ho1: There is no significant relationship between socio economic characteristics of the respondents and type of enterprise mix in integrated fish farming.

\section{Materials and methods}

The study was carried out in Ogun State of Nigeria. The state is situated within the Tropic covering 16,409,29 square kilometer with a population of about 4,052,272, (NPC 2006) Ogun state is administratively divided into twenty local Government which was further grouped into four(4) agricultural zones. These are Abeokuta, Ilaro, Ikenne and Ijebu-ode. Each zone is divided into blocks and cells for ease of extension services within the state.

\subsection{Sampling procedure and sampling size}

Purposive random sampling techniques was used for this study, the four agricultural zones was purposely selected where integrated fish farmers was predominant, ten agricultural extension blocks were selected by purposive random sampling from the zone out of the 20 extension blocks. From each of the blocks, 2 extension cells were randomly selected and also 11 farmers were randomly selected for the interview from a list of 
integrated fish farmers. In all 220 farmers were sampled out of which 216 were available for the interview. Primary data were collected from the respondents using a well structures interview guide. Descriptive statistical tools were used to describe the socio-economic characteristics of the respondents and various enterprise $\mathrm{mix} /$ combination. Chi-square analysis $\left(\chi^{2}\right)$ and bivarate analysis was also use to test the stated hypotheses.

\subsection{Measurement of variables}

Age: The actual age of the respondents was obtained in years.

Sex: Respondents indicated whether they are male $=1$ female $=2$. Frequency counts and percentages were then used to interpret the data generated.

Educational attainment: Respondents indicated their level of educational attainment from the list of eight options provided as:
a) No formal education,
b) Primary,
c) JSS/Modern III,
d) Secondary
e) Technical/Grade II,
f) OND/NCE,
g) HND/B.Sc, h) Postgraduates

Main occupation: Respondents were asked to indicate their main occupation.

Mode of involvement in fish farming: This was measured by asking the respondents to indicate whether they are full time (1) part time (2)

Number of years of involvement in fish farming: Respondents were asked to state the number of years they have been involved in fish farming and this was measured at interval level.

Nativity: This was measured as native (1) and non native (2)

Fish production capacity: Respondents indicated their capacity in fish farming. This includes: below 5000 fingerlings, 5000-10000 fingerlings (moderate) and above 10000 fingerlings. This was measured at interval level.

Livestock population capacity: Respondents indicated the number of livestock in their farms. This was also categorised into: relatively small $(<5000)$ herds of livestock, above average $(5000-10000)$ herds of livestock and relatively large $(>10000)$ herds of livestock. Data collected was measured at interval level.

Area of crop land cultivated: Respondents indicated the size of land cultivated. The dimension of the land were categorised as follows: below 1 hectare of land, 1-3 hectares of land and above 3 hectares of land. Information collected was measured at interval level.

Integrated fish farming activities: These include the type of crops planted and animals reared. Respondents were asked to list different crop planted and animal reared in combination with fish farming. Combinations recorded were: a) Fish cum arable crops, b) Fish cum Tree crop, c) Fish cum poultry, d) Fish cum piggery, e) Fish cum goat cum sheep.

Knowledge of fish farming: This was measured using 19 adoptable technologies. The extent of knowledge was measured using 4 point rating scale of "Very well" which attracted 3points, "fairly well" 2points, "have ideas" 1 point and not at all zero point. This gave a maximum score of 57 and minimum score of 19points and this was used to categorise farmers' knowledge into different levels.

\subsection{Data analysis}

The data was analysed using both descriptive and inferential statistics. Descriptive statistics was used to achieve the highlighted objectives while inferential statistics such as chi square and Pearson product moment Correlation was used to test the hypotheses.

\section{Result and discussion}

\subsection{Socio economic factors of the respondents}

Table 1 shows the mean age of the respondents 44 years, indicating that majority of the respondents were within economically active age category (FAO, 1997; Yunusa, 1999). In support of this result, Fakoya and Daramola (2005) observed that respondents within this age bracket are more innovative, motivated and adaptable individuals who can with wisdom cope with farming challenges. Respondents in the age bracket $40-50$ years are more involved in integrated fish farming ( 38.0 percent). The percentage range between the farmers under study is a pointer to the fact that much commitment either in terms of finances or experience is needed to cope with farm operations especially with integrated fish farming (IFF) with multiple enterprises which recorded the highest value (38.0 percent). The age bracket $30-40$ years is another important age category with strength for mobility to tackle some of the task on the farm. In this age bracket, $27.8 \%$ was recorded for integrated fish 
farmers (IFF) .It could be recalled that, the above age category are youth who have the capacity to explore and withstand farm stress.

Sex is an important factor to consider in farming activities or any other energy demanding exercise. Out of all the respondents sampled, 90.7 percent were male while 9.2 percent were female. This result can be justified by the assertion of Brummett et al. (2010) that fisheries activities are mostly dominated by men. However, the observation can also be said to be contrary to the report of Worby, (2001) who reported that women are often motivated than men to adopt new technologies that provides nutritional benefits such as fish culture. Based on the technologies involved which may be energy demanding, farming occupation is largely controlled by men and this may be due to the general belief that men are more energetic than women. The finding can be further supported by the assertion of Ekong, (2003) that women play minimal roles in farming among Yorubas.

Considering the educational level of sampled farmers in the study area, it was revealed that majority (81.5 percent) of the respondents had secondary and tertiary education. It is also worthy of note that the respondents had different levels of education based on their indicated acquired degrees. Although, a relatively small proportion of integrated fish farmers (5.6 percent) had no formal education while 13.0 percent had primary education. The high level of education recorded in this study might be due to the metropolitan nature of the study area and its implication is that the respondents according to Olagunju et al. (2007) may be very receptive to new innovations. This result shows that at least more than half of the respondents had the capacity to learn new innovation within a short period of time based on their level of education.

Occupation remains valid in our society as people have one or two things they engaged in which give them sense of belonging in our society. Looking at the occupational status of the respondents, majority (58.3percent) of integrated fish farmers (IFF) engaged more in farming activities. It is obvious that 21.8 percent of integrated fish farmers were in the paid employment (the class who choose farming as second class occupation). Based on farmer's response during field survey, it was discovered that some of the respondents engaged in other occupation apart from farming. Furthermore, it was recorded that 1.9 percent of the respondents belong to other occupational class or the other. This observation showed that non-farm activities are becoming important in our society, especially in the communities with closer proximity to the cities. This can be supported by the assertion of Ellis (1999) that farming on its own is rarely sufficient for household needs in rural African settings. Trading and other little businesses were other things they engaged in. Adducible reason for this occurrence is as a result of multiple enterprises combination in integrated fish farming which may take more of their attention. In all, it can be established that the respondents in this study seek for different livelihood strategies and economic portfolios which could assist their food security and income generation which is very common practice among farmers (Ashley and Carney 1999; Ellis, 1999 ; Toulmin et al., 2000).

Notable percentage (59.3 percent) of integrated fish farmers were full time farmers. While 40.7 percent of the respondents belong to the group of part time farmers Higher value (59.3 percent) recorded for integrated fish farmer (IFF) as full time farmers which is a further confirmation that they have much engagement with several farm enterprises which take most of their time unless they delegate their responsibility to do other farm activities/enterprises.

Experience played prominent role in any farming enterprise, from the findings of this study 60.2 percent of integrated fish farmers had 1-5 years experience while 28.7 percent of the farmers that had 6-10 years experience in fish farming, only 11.1 percent of integrated fish farmers had over 10 years experience. This implies that this aspect of farming is still very new compared to other farming practices like mixed farming or rotational farming which had being in existence for over 100 years ago. As a result of this, there is need for more subject matter specialist in this area of farming to assist rapid dissemination of information to practicing and intending farmers in the nearest future.

Based on the nativity of the respondents, it was also revealed that, majority ( 88.0 percent) of the respondents were native of Ogun State while 12.0 percent were non native. Of those that were native. This observation may be attributed to the geographical and occupational distribution as well as infrastructural provision of the respondents' household which favours these two types of farming (Fapojuwo, 2007).

\subsubsection{Level of cosmopoliteness of the respondents}

The distribution of sampled farmers by their frequency of visit outsides their native communities are presented in Table 2. For low level of cosmopolitness, integrated fish farmer (IFF) had the highest value (35.2 percent). At moderate level, 41.2 percent was recorded for integrated fish farmer (IFF) while at high level (above 156 days/year), 23.6 percent was recorded for IFF. Movement of farmers to other communities within their local government areas or even within the state may be for the pursuit of inputs such as feed, seed, information, 
training, fingerlings procurement and even to see other farms. Increase in numbers of visit between the farmers may be for any of the above mentioned reasons. Notable reason could also be as a result of proximity of these towns to each other as some of the farmers may not be living in the community in which they farm. The movement pattern of farmers as tracked down in this study can be supported by the findings of Nwabude (1995) cited by Fapojuwo (2007) who asserted that a high level of cosmopoliteness is reported among members of farming household in Ogun State. Increase in number of visit recorded by integrated fish farmers (41.2 percent) at moderate level of cosmopolitness (52-156 days/year) may be an indication of searching for information in newly adopted technologies in integrated fish farming. This observation can be further supported by the findings of Olowu et al (1990) that farmers' cosmopoliteness is a significant determinant of the adoption of new technologies. Islam et al (2007) further assert that farmers with higher expenditure had better economic and social status in the community, which makes them mobile and cosmopolite and also increase his/her communication exposure which ultimately contributes to the extent of use of knowledge system more efficiently by the farmers.

\subsubsection{Fish production capacity}

Fish production capacity of the respondents depends on their financial status, environmental factor, cultural values and religion factors. Table 3 presents the fish production capacity of the farmers. The result of this study shows that, 31.9 percent of integrated fish farmers (IFF) have capacity to raise below 5000 fishes to table size. This observation may be related to the size of their pond capacity or the farmers' financial strength in terms of their stocking ability which are not as high as others. Likewise, 32.4 and 35.6 percent values recorded for between 5000-10,000 and above 10,000 capacity to raise fish for integrated fish farmers (IFF) is a reflection of higher capacity. Waste recycling mechanism of integrated fish farming which reduces cost of production may be one of the reasons for this observation. This observation is also in line with the report of Inoni, (2007) who assert that fingerling stocking among other factors is a determinant of capacity of fish production. Improving yield in fish farming requires the stocking of fast growing fingerlings of economically viable fish species, if the farmers must realise his/her objective of maximising revenue and profit (Hatch et al, 1995; khan, 1986; Merola and Pagan- Font, 1988).

\subsubsection{Livestock population capacity}

Livestock population capacity of the respondents sampled was investigated. Table 4 shows the respondents livestock population capacity in the study area. It was discovered that 41.7 percent of integrated fish farmers had livestock population capacity less than 5000. Likewise, for the category of farmers that had 5000 - 10000 herds, 34.3 percent was recorded for integrated fish farmers while 24.1 percent of the respondents had more than 10000 herds.

This result is an indication that integrated fish farming in the study area has not reached the maximum state as compared to other country like China where they have larger livestock population. However, it is promising that with time, more protein will be made available to our growing population as fish farming is been incorporated to both crop and livestock farming practices. According to Fernando and Halwart (2000), fish farming has become an important enterprise because land and water have become more and more in demand to produce more food of better quality to feed the growing population. If fish farming is then integrated as expected, it is hopeful that more food will definitely be available. Based on the result of this study, Agricultural Extension service in the country need to be empowered in such a way that farmers will have access to necessary information that help them in their farming activities.

\subsubsection{Area of crop land cultivated}

The data on area of crop land cultivated by the respondents are presented in Table 5, this aspect involved only one category of farmer (integrated fish farmer (IFF). Obviously, 28.7 percent of the respondents cultivated more on a crop land below 1 hectare. For $1-3$ hectares of land cultivation, 25.9 percent of integrated fish farmers feature prominently. Above 3 hectares of land, only 12.0 percent of integrated fish farmers (IFF) cultivated on a crop land of this size. Reason for this observation may be as a result of combination of different farming enterprise that would lead to generation of enough waste which will serve as inputs for other enterprise because of the large number of fish stocked or other livestock involved to reduce overall cost of production. The outcome of this study is in agreement with the report of Okuneye (1992) which stated that farmers will always used the land size in which they can manage.

\subsection{Different enterprise combination of integrated fish farming}

As pointed out by Eyo et al, (2006), integrated fish farming is the association of two or more normally separate farming system, which become part of the whole farming system. This section presents enterprise combination in 
integrated fish farming of sampled respondents in the study area. Table 6 presents enterprise combination in integrated fish farming. It is obvious from this study that, 11.5 percent of integrated fish farmers were involved in fish cum poultry as an enterprise mix. Fish cum pig accounted for 7.2 percent in the study area. Farmers' action towards the embracement of this area of farming is in agreement with the report of Fakoya and Daramola (2005) which asserted that integration of fish and poultry can reduce cost incurred on fertilizers and feeds in fish culture and maximize income. For respondents that integrate fish with crop, fewer percentages were recorded.

In addition, association of fish with livestock is another enterprise combination investigated in this study. For fish cum small ruminant, 1.4 percent of the respondents fall into this category. Combination of more than two enterprises was found to be prominent among integrated fish farmers. Values such as 14.6, 2.3, 6.6 and 2.0 percents were recorded for fish cum poultry cum crops, fish cum pig cum crops, fish cum poultry cum piggery cum crops and fish cum poultry cum pig cum small ruminant. This result could be further supported with the assertion of ICLAM, (2001) that in integration, only compatible enterprise can be combined with fish culture. This may be one of the reasons why few respondents opted for other options and appreciable number (14.6 percent) were found in fish cum poultry cum crops. Other reason may be that poultry litter has been known to be very rich in nutrients thereby supporting both crops and fish as compared to other animal droppings such as those of pigs, goats and sheep (small ruminant).

\subsection{Result of the hypotheses}

The correlation coefficient obtained from the statistical analysis in Table 7 shows that, there was a significant relationship between knowledge of the farmers (integrated fish and non integrated fish farming) and age $(r=0.20$, $\mathrm{p}<0.02)$ and fish farming experience $(\mathrm{r}=0.17, \mathrm{p}<0.00)$. This result is in agreement with the report of Adeniji (2005) who reported a similar significant relationship between age and knowledge among farmers. The implication of this result is that, the prominent age category of the respondents between the two different types of farming categories may be responsible for the trend of this result. In other words, as the age of the respondents increases, their knowledge in fish farming also increase which further shows their interest in fish farming. Furthermore, there were significant relationship between knowledge and cosmopoliteness, fish production capacity, livestock population capacity and area of crop land cultivated $(r=-0.16, p<0.01),(r=0.21, p<0.00)$, $(\mathrm{r}=0.36, \mathrm{p}<0.00)$ and $(\mathrm{r}=0.55, \mathrm{p}=<0.00)$.

Table shows the result of chi-square analysis. There are significant relationship between knowledge of fish farming and marital status $\left(\chi^{2}=23.2, p<0.05\right)$, occupation $\left(\chi^{2}=25.5, p<0.05\right)$, mode of involvement $\left(\chi^{2}=17.1\right.$, $\mathrm{p}<0.05)$ land acquisition $\left.\left(\chi^{2}=26.4, \mathrm{p}<0.05\right)\right)$ and extent of group participation $\left(\chi^{2}=12.5, \mathrm{p}<0.05\right)$, while no significant relationship was recorded between educational level $\left(\chi^{2}=10.79, p>0.05\right)$, religion $\left(\chi^{2}=1.20, p>\right.$ $0.05)$, nativity $\left(\chi^{2}=2.51, p>0.05\right)$ and knowledge of fish farming.

Table shows the result of chi-square analysis. There are significant relationship between knowledge of fish farming and marital status $\left(\chi^{2}=23.2, p<0.05\right)$, occupation $\left(\chi^{2}=25.5, p<0.05\right)$, mode of involvement $\left(\chi^{2}=17.1\right.$, $\mathrm{p}<0.05)$ land acquisition $\left.\left(\chi^{2}=26.4, \mathrm{p}<0.05\right)\right)$ and extent of group participation $\left(\chi^{2}=12.5, \mathrm{p}<0.05\right)$, while no significant relationship was recorded between educational level $\left(\chi^{2}=10.79, \mathrm{p}>0.05\right)$, religion $\left(\chi^{2}=1.20, \mathrm{p}>\right.$ $0.05)$, nativity $\left(\chi^{2}=2.51, p>0.05\right)$ and knowledge of fish farming.

\section{Conclusion and Recommendations}

The results of the study indicated that respondents were found to integrate fish cum poultry and fish cum crop farming. Few of them were involved in one enterprise mix or the other which help the farmers to manage their resources very well. Based on the results of the study the following recommendations are proposed.

1) Efforts should be geared towards increasing the awareness on the importance of enterprise mix in integrated fish farming by expert in extension services

2) Provision of credit and proper incentives such as land, herbicides and construction of good access roads for easy transportation of farm produce.

3) Government policies and measures should aid the practice such as allocation of enough land to interest farmers so that there would be a better means of land acquisition.

\section{References}

Abiona, B. G. (2010). Comparative analysis of Integrated and Non- Integrated fish farming in Ogun State, Nigeria. Unpublished $\mathrm{PhD}$ Thesis form Department of Agricultural Extension and Rural Development, University of Agriculture, Abeokuta.Ogun State, Nigeria. 
Adeniji, G. B. (2005). Training Need of Extension Agents in Agricultural Development Programmes of selected states of South Western Nigeria. Journal of Agricultural Extension, 9: pp 31 - 37.

Aderibigbe, A. F. O. (1994). An assessment of the linkage between extension services of OGADEP and inputs supply system. Unpublished B. Agric. Project, Department of Extension and Rural Development, University of Agriculture, Abeokuta, Nigeria.

Ashley, C. \& Carney. D. (1999). Sustainable Livelihoods: Lessons from Early Experience. London: Department for International Development.

Brummett, R. E., Youaleu, J. L. N., Tiani, A. M., \& Kenmegne. (2010). Women's traditional fishery and alternative aquatic resource livelihood strategies in the Southern Cameroonian Rainforest. Fisheries Management and Ecology, 17, 221-230. http://dx.doi.org/10.1111/j.1365-2400.2009.00702.x

Chaplin, H., Davidove, S. \& Gortom, M. (2002). Non-Agricultural diversification of farm households and corporate farms in Central Europe. Imperical College, Unversity of London, Wye campus. pp 2-5.

Ekong, E. E. (2003). An Introduction to Rural Sociology $\left(2_{\text {nd }}\right.$ ed) Dove Educational Publishers, Uyo, Nigeria. pp 167.

Ellis, F. (1999). Rural Livelihood Diversity in Developing Countries: Evidence and Policy.

Eyo, A. A., Ayanda, J. O. and Adelowo, E. O. (2006). Essentials of Integrated Fish Farming, National Institute for Freshwater Fisheries Research, New Bussa. pp 12-20.

Fakoya, E. O. \& Daramola, B. G. (2005). Socio Economic Factors Influencing Farmers Participation In Integrated Fish Farming Published Rural Sociology Journal. pp2.

FAO. (1997). Review of the state of World Aquaculture. FAO Fisheries Cir., 886 (Rev.1)

Fapojuwo, O. E. (2007). Cassava processing techniques and household food security of women processing in Ogun State, Nigeria PhD thesis, Department of Agricultural Extension and Rural Development, University of Ibadan, pp $111-175$.

ICLARM. (2001). Integrated agriculture-aquaculture: A Primer. FAO Fisheries Technical Paper. FAO Rome. 2001. pp 4-8, 144.

Inoni, O. E. (2007). Allocation efficiency in pond fish production in Delta State, Nigeria: A functional Approach. Agricultural Tropical Et Subtropica, 40 (4): pp 127-134.

Islam, M. S., Uddin, M. E. \& Rashid, M. U. (2007). Use of Knowledge System in the Rural Community in Improving Livelihood Status of the Farmers under RDRS. J Agric Rural Dev, 5(1\&2), 167-17.

Jhingran, A.G. (1986). Integrated fish-livestock-crop farming and its role in developing rural economy. Bull. Cent. Inland Fish. Res. Inst., Barrackpore, (48): 1. pp 1-4.

Nash E, Collins FH., Brown J., \& Carol M. (1980). A Theoretical comparison of waste treatment processing ponds and fish products ponds receiving animal wastes. In: R.S.V Pullin and Z.H. Shehadeh (eds). Integrated Agriculture- Aquaculture farming system ICLARMSEARCH Manila, Phillipinnes. pp. 87-97.

NPC. (2006). National Population Commission (NPC) (2006): www.onlinenigeria.com Accessed on $4^{\text {th }}$ February 2009.

Nwabude, A. A. (1995). Identification of Suitble Communication Channels for Ogun State Farmers. MSc. Thesis, Department of Agricultural Extension and Rural Development, University of Ibadan, pp 107

Ogun state of Nigeria. (1998). Ogun State Diary, Ogun state of Nigeria. pp. 12 OGADEP, 2002: Annual reports. OGADEP, Abeokuta. Pp 8.

Okuneye, P. A. (1992). The problem of declining food production. In Olarewaju, S .A. \& Oladosu GA, Ayinla OA, Onuoha GC, Mecdom JG. 1990. Performance of Clarias gariepinus in a polyculture with Orechromis niloticus under the integrated broiler chicken fish farming. NIOMR Technical/paper, pp.65.

Oladosu G. A., Ayinla O .A., Onuoha G.C., \& Mecdom J.G. (1990). Performance of Clarias gariepinus in a polyculture with Orechromis niloticus under the integrated broiler chicken fish farming. NIOMR Technical/paper, pp.65.

Olagunju, F. I., Adesiyan, I. O., \& Ezekiel, A. A. (2007). Economic viability of cat fish production in Oyo State, Nigeria Journal of Human Ecology, 21 (2): pp 121-124. 
Olowu, T. A.; Iloka, A. I. \& Ekpere, J. A. (1990). Farmers Characteristics and adoption of Improved Cassava Varities in Imo State, Nigeria. Journal of the Nigerian Academy of science, 2: pp 93-100.

Toulmin, C., R. Leonard, K. Brock, N. Coulibaly, G. Carswell, \& D. Dea. (2000). Diversification of Livelihoods: Evidence from Mali and Ethiopia. Research Report 47, University of Sussex, Institute of Development Studies, Brighton, U.K.

Worby, E. (2001). Sociocultural considerations when introducing a new integrated agriculture-aquaculture technology, In: FAO Fisheries technical paper. FAO, Rome. pp 3-8.

Yunusa, M. B. (1999). Not farms alone: study of rural livelihood in the middle belt of Nigeria. DAREASC Working Paper 38.

Table 1. Distribution of respondents by their socio economic characteristics

\begin{tabular}{|l|lr|}
\hline Variables & Integrated fish farming n $=216$ & \\
\hline Age(years) & Freq & 1.9 \\
\hline Below 30 years & 4 & 27.8 \\
\hline $30-<40$ & 60 & 38.0 \\
\hline $40-<50$ & 82 & 24.1 \\
\hline $50-<60$ & 52 & 8.3 \\
\hline 60 and above & 18 & \\
\hline Mean age & $\mathbf{4 6}$ & \\
\hline Sex & & 90.7 \\
\hline Male & 196 & 9.2 \\
\hline Female & 20 & 13.0 \\
\hline Educational status & & 47.7 \\
\hline No formal education & 12 & 33.8 \\
\hline Primary education & 28 & 4.2 \\
\hline Secondary education & 103 & 58.3 \\
\hline Tertiary education & 73 & 21.8 \\
\hline Occupation & & 9.3 \\
\hline Artsianship and craft & 9 & 1.9 \\
\hline Farming & 126 & 59.3 \\
\hline Paid employment & 57 & 40.7 \\
\hline Trading & 20 & 28.7 \\
\hline Others & 4 & 11.1 \\
\hline Mode of involvement & & \\
\hline Full time & 128 & \\
\hline Part time & 88 & \\
\hline Fish farming experience(years) & & \\
\hline 1 -5 & 130 & \\
\hline $6-10$ & 62 & \\
\hline Above 10 & 24 & \\
\hline Nativity & & \\
\hline Native & & \\
\hline Non native & & \\
\hline & & \\
\hline
\end{tabular}

Source: Field survey, 2009 
Table 2. Distribution of respondent by their level of cosmopoliteness $n=216$

Source: Field survey, 2009

\begin{tabular}{|l|l|l|l|l|}
\hline Variables & \multicolumn{2}{|l|}{ Integrated fish farming } & \multicolumn{2}{l|}{ Total response } \\
\hline Cosmopoliteness & Freq & $\%$ & Freq & $\%$ \\
\hline Low $(<52$ days/year) & 76 & 35.2 & 76 & 35.2 \\
\hline Moderate(52 - $<156$ days/year) & 89 & 41.2 & 89 & 41.2 \\
\hline High $(>156$ days/years) & 51 & 23.6 & 51 & 23.6 \\
\hline
\end{tabular}

Table 3. Fish production capacity of the respondents $n=216$

\begin{tabular}{|l|l|l|l|l|}
\hline Variables & \multicolumn{2}{|l|}{ Integrated fish farming } & \multicolumn{2}{l|}{ Total response } \\
\hline Fish production capacity & & & & \\
\hline Below 5000 & 69 & 31.9 & 69 & 31.9 \\
\hline $5000-10000$ & 70 & 32.4 & 70 & 32.4 \\
\hline Above 10000 & 77 & 35.6 & 77 & 35.6 \\
\hline
\end{tabular}

Source: Field survey, 2009

Table 4. Livestock population capacity by respondents $n=216$

\begin{tabular}{|l|l|l|l|l|}
\hline Variables & \multicolumn{2}{|l|}{ Integrated fish farming } & \multicolumn{2}{l|}{ Total response } \\
\hline Livestock population capacity & Freq & $\%$ & Freq & $\%$ \\
\hline Relatively small $(<50000)$ & 90 & 41.7 & 90 & 25.8 \\
\hline Above average $(5000-<10000)$ & 74 & 34.3 & 74 & 21.2 \\
\hline Relatively large $(>10000)$ & 52 & 24.1 & 52 & 14.9 \\
\hline
\end{tabular}

Source: Field survey, 2009

Table 5. Area of crop land cultivated by respondents $n=216$

\begin{tabular}{|l|l|l|l|l|}
\hline Variables & \multicolumn{2}{|l|}{ Integrated fish farming } & \multicolumn{2}{l|}{ Total response } \\
\hline Area of crop land cultivated & Freq & $\%$ & Freq & $\%$ \\
\hline Below 1 hectare & 62 & 28.7 & 62 & 17.8 \\
\hline $1-3$ hectares & 56 & 25.9 & 56 & 16.0 \\
\hline Above 3 hectares & 26 & 12.0 & 26 & 7.4 \\
\hline
\end{tabular}

Source: Field survey, 2009

Table 6. Enterprise combination in integrated fish farming

\begin{tabular}{|l|c|c|}
\hline Variables & Freq & $\%$ \\
\hline Sole fish farming & 133 & 38.1 \\
\hline Fish cum poultry & 40 & 11.5 \\
\hline Fish cum piggery & 25 & 7.2 \\
\hline Fish cum crop & 55 & 15.8 \\
\hline Fish cum small ruminant & 5 & 1.4 \\
\hline Fish cum poultry cum piggery & 2 & 6.0 \\
\hline Fish cum poultry cum crops & 51 & 14.6 \\
\hline Fish cum piggery cum crops & 8 & 2.3 \\
\hline Fish cum poultry cum piggery cum crops & 23 & 6.6 \\
\hline $\begin{array}{l}\text { Fish cum poultry cum piggery cum crops } \\
\text { cum small ruminant }\end{array}$ & 7 & 2.0 \\
\hline
\end{tabular}

Source: Field survey, 2009 
Table 7. Correlation analysis of the respondent's socio economic characteriscs and their knowledge of integrated fish farming

Source: Field survey, 2009

\begin{tabular}{|l|c|c|c|}
\hline Variable & R & P & D \\
\hline Age & 0.20 & 0.00 & S \\
\hline Fish farming experience & 0.17 & 0.00 & S \\
\hline Level of cosmopoliteness & 0.16 & 0.01 & S \\
\hline Livestock population & 0.21 & 0.00 & S \\
\hline Fish production capacity & 0.36 & 0.00 & S \\
\hline Area of crop land cultivated & 0.55 & 0.00 & S \\
\hline
\end{tabular}

Note: $\mathrm{S}=$ Significant at 0.05 level

NS $=$ Not Significant at 0.05 level

Table 8. Chi -square analysis of respondents socio economic characteristics and their knowledge of integrated fish farming

\begin{tabular}{|l|c|c|c|c|}
\hline Variables & $\chi^{2}$ & Df & CC & Decision \\
\hline Sex & 9.44 & 2 & 0.00 & S \\
\hline Educational status & 10.79 & 6 & 0.09 & NS \\
\hline Occupation & 25.5 & 8 & 0.01 & S \\
\hline Mode of involvement & 17.1 & 2 & 0.00 & S \\
\hline
\end{tabular}

Source: Field survey, 2009

Note: $\mathrm{S}=$ Significant at 0.05 level

NS $=$ Not Significant at 0.05 level 